cautious in expressing personal views, a circumstanco, by the way, that medical students will find unusual but which ought to do thom a lot of good. Teachors will also probably find the anatomical parts oxplainod with greater lucidity than the more rocondito probloms of visual physiology whore, as is inevitablo in as catholic an approach as Davson has succe日ded in following, a fow inconsistencies have crept in. Examiners, though the smallest but perhaps the most important group of peopl $\rightarrow$ who may turn to this book, will be in a quandary. If thoy are omniscient-and thoy would scarcely bo examiners if they were not-they will realize that this book contains horesios, and that in some rospocts it is already out of dato. Are they going to mark a studont's performance on his ability to provide answers to the questions they have set or on his ability to roproduce the gospel according to this book? They will allow their judgment to be governed by the book in matters which are well established or boyond dispute, but would bo wise to tolerate an unexpected answor on the studont's part if this appears reasonable.

R. A. WEari

\section{PORPHYRIN DISORDERS}

Diseases of Porphyrin Metabolism

By A. Goldberg and Prof. C. Rimington. (A Monograph in the Bannerstone Division of American Lectures in living Chemistry.) Pp. xvi +231. (Springfield, Ill.: Charles C. Thomes, 1962.) 9.75 dollars.

$\mathrm{D}$ ISCOVERIES in puro science usually precede their developments in appliod science, and it is refreshing to encounter a topic in which both forms of science have in turn contributed equally to knowledge. This is ospocially true of the developmont of our understanding of porphyrin metabolism. Towards the end of the ninoteenth century and the beginning of this, Garrod and other clinicians in Britain and in Germany observed rod pigmonts in tho urine and fæees of patients with certain diseases. The first sciontific advances were made by Fischer and his colleagues, who investigated the chemistry of these porphyrin pigments and established their chomical structures and synthesized them. In 1935 Waldenstrom, a clinician, demonstrated the presence of porphobilinogen (PBG), a colourless precursor of porphyrins, in the urine of subjects with acute intermittent porphyria. This condition was thus clearly distinguishod from congenital or photosensitive porphyria in which large amounts of preformed porphyrins woro excreted. In 1946, Shernin and Rittenberg showed that, in the rat and in normal rnan, glycine was specifically incorporated into the protoporphyrin of the circulating hæmoglobin. Subsequent work by British and Arnerican groups showed that the uroporphyrin and coproporphyrin of Series I excreted by patients with congenital porphyris wero synthesized from the same precursor as the protoporphyrin of the circulating hæm, even though this pigment belonged to Series III. Acetate was thon found to be incorporated into hæm, and tho brilliant work of Shemin involving the chemical degradation of the labelled protoporphyrin isolated from hæmoglobin after fooding ${ }^{14} \mathrm{C}$ - and ${ }^{15} \mathrm{~N}$ labolled glycino and ${ }^{14} \mathrm{C}$-acetic acid showed the origins of all the atoms of this compound. This worker suggested that the protoporphyrin was synthesized by way of a monopyrrolic precursor formed by condensation of two moloculos of an asymmetric four-carbon compound derived from glycine and acetic ucid. Four molecules of the monopyrrole condensed to yield uroporphyrinogen from which coproporphyrinogen and protoporphyrin were afterwards formod. The monopyrrolic precursor was thought to be porphobilinogen and its isolation by Westall was a triumph for a clinical chomical department; progress then had to await the establishment of its structure by Cookson and Rimington and its synthesis by Jackson and
Macdonald. This was soon followed by the demonstration of the enzymatic synthesis of porphobilinogen fromsuccinyl coenzymo $A$ and glycino via $\delta$-aminolaevulic acid (ALA). Since then there have been meny investigations on the mechanism of specific formation under physiological conditions of Series III porphyrins.

Tho disturbances of this biosynthetic pathway ro. sponsible for the various clinical disorders of porphyrin metabolism are now subjects of intensive study in a number of laboratories throughout the world. Although many dotails remain to be filled in, our knowledge has progressed considerably and has supportod Garrod's concept that these inborn errors of metabolism were due to enzymatic deficiencies. The precise abnormality leading to the excessive excretion of ALA and PBG in acute porphyria, however, remains to be elucidated.

The time is ripe for a comprehonsive roview of our knowledge of the porphyrins and of the diseases associated with disturbances of their metabolism and we are fortunate in having this book, the senior author of which has contributed so much to this subject since he first recognized the importance of porphyrins at a $\operatorname{tim} \theta$ when they were little more than biochemical curiosities. Dr. Goldberg has made important contributions both to tho clinical aspects of the disease and to the mechanisms of production of the experimental porphyrias. The first chapter concerns general aspects of the porphyrias, thoir classification and geographic distribution, and the second discusses the chemistry and biosynthesis of the pigments themselves and their distribution in the body. There follow successive chapters on congenital (erythropioetic) porphyria, acute intermittent porphyria and the various forms of cutaneous porphyria. Each is described from both the clinical and the chemical points of view. Subsequent chapters concorn disoases of porphyrin metabolism other than the porphyrias, the incidence of porphyria in animals, and include an account of the various forms of experimental porphyria. It is a pity thet the recent discovery of griseofulvin-induced porphyria was made too late to bo included.

Nevertholess, it is difficult to praise this monograph too highly; the format and stylo are well up to the standard set by the series. In particular, the photographs of pationts and the microphotographs of tissues, coloured when demonstrating the presence of fluorescent porphyrins, are excellent and the list of references is up to date to 1961. It is unlikoly that this book will be read by all clinicians, all pathologists or all biochemists; it will b9 of very great interest to clinicians who have actually oncountered pationts with disorders of porphyrin meta. bolism, espocially nourologists who have seen the devas. tating sequelæ the disease can leave in the nervous system, and dormatologists who will learn of the various forms of porphyria which can cause photosensitivity. To the pathologist the subject illustrates beautifully the way science and medicine have developed to mutual advantage, while for the biochomist the book reveals many remaining problems especially in determining the details of abnormalities in enzymatic syntheses responsible for these intoresting disoasos.

C. H. Gray

\section{RARE EARTH AND ACTINIDE SPECTRA}

\section{Operator Techniques in Atomic Spectroscopy}

By Prof. Brian R. Judd. (MeGraw-Hill Advancod Physics Monograph Series.) Pp. ix +242 . (London and New York: McGraw-Hill Book Company, Inc., 1963.) 778.

$T$ was round sbout 1948 that the olectron spin rosonance group at Oxford began to investigate rare earth salts, and theroby created for themselves an urgent need to 